\title{
End Matters
}

(C) Springer Science+Business Media, LLC 2010

\section{Conferences of Note}

European Psychiatric Association (EPA) Annual Meeting

Vienna, Austria

March 12-15, 2011.

Society for Psychological Anthropology (SPA) Biennial Meetings

Santa Monica, CA, USA

March 31-April 3, 2011.

American Association for the History of Medicine (AAHM)

Philadelphia, PA, USA

April 28-May 1, 2011.

American Psychiatric Association (APA) 164th Annual Meeting

Honolulu, HI, USA

May 14-18, 2011.

10th World Congress of Biological Psychiatry of the World Federation of Societies of Biological Psychiatry (WFSBP)

Prague, Czech Republic

May 29-June 2, 2011.

\section{Books Received}

J. M. Molina and D.K. Swearer

2010 Rethinking the Human. Cambridge, MA: Center for the Study of World Religions.

L. Kapteijns and A. Richers, eds.

2010 Mediations of Violence in Africa. Leiden, the Netherlands: Brill. 